\title{
A POSZTTRAUMÁS STRESSZ SZINDRÓMA (PTSD) TÖRTÉNETI ÁTTEKINTÉSE, A TRAUMA FELOLDÁSÁNAK LEHETŐSÉGEI
}

Szerzők:

Fejes Csenge

Pázmány Péter Katolikus Egyetem

Révay Rebeka

Károli Gáspár Református Egyetem

Első szerző e-mail címe:

csengefejes14@gmail.com
Lektorok:

Fejes Zsolt (PhD)

NATO Joint Force Command, Naples

Mihók Sándor (Dr. Jur.)

nyugalmazott jogtanácsos

...és további két anonim lektor

\section{Absztrakt}

A történelem során egészen az ipari forradalomig a poszttraumás stressz szindróma (PTSD) tüneteit kizárólag a katonák betegségeként tartották számon. Napjainkra már tudjuk, hogy a tünetegyüttes traumatikus életesemények után alakulhat ki, amelyek olyan intenzitással hatnak, hogy a személy képtelen ellenük védekezni. Az átélt súlyos, halállal, komoly sérüléssel vagy erőszakkal fenyegető történés idegrendszeri változásokat, illetve változatos pszichés tüneteket okoz, amelyek hosszú ideig fennállnak és jelentős hatást gyakorolnak az egyén életére. Tanulmányunkban a PTSD diagnosztikájának történelmi állomásait vizsgáljuk meg az ókortól egészen napjainkig, kitérve a trauma fogalmának alakulására, jelentőségére is.

Kulcsszavak: poszttraumás stressz szindróma (PTSD), trauma, hadviselés történelme, háborús neurózis, tüzérségi sokk, DSM-V

Diszciplínák: pszichológia

\begin{abstract}
HISTORICAL OVERVIEW OF POST-TRAUMATIC STRESS SYNDROME (PTSD), POSSIBILITIES FOR RESOLUTION OF TRAUMA

Throughout history, until the Industrial Revolution, the symptoms of post-traumatic stress disorder (PTSD) were considered a disease which spread only among soldiers. Today we know that the syndrome can develop after traumatic life events, which are so intense that the person is unable to protect oneself. After experiencing threatening death, violence or getting seriously injured, changes start to develop in the nervous system which causes a variety of psychiatric symptoms. These physiological consequences can last for a long time and have a significant impact on the person's life. In our study we would like to examine the historical stages in the
\end{abstract}


diagnosis of PTSD from antiquity to the present day, including the development and significance of the concept of trauma.

Keywords: post-traumatic stress disorder (PTSD), trauma, history of warfare, war neurosis, shell shock, DSM-V

Disciplines: psychology

Fejes Csenge és Révay Rebeka (2021): A poszttraumás stressz szindróma (PTSD) történeti áttekintése, a trauma feloldásának lehetőségei. Lélektan és hadviselés - interdiszciplináris folyóirat, III. évf. 2021/2. szám. 63-75. doi: 10.35404/LH.2021.2.63

Bár a poszttraumás stressz szindróma (a továbbiakban PTSD) vizsgálata leginkább az I. és II. világháború idején kapott nagy hangsúlyt, története mégis egészen az ókorig nyúlik vissza, sôt, a tünetek megjelenése tulajdonképpen egyidős az emberrel. Több olyan ókori művel is találkozhatunk, amelyek beszámolnak a PTSD tipikus tüneteiről, mint a visszatérô rémálmok, az alvászavarok, a traumatikus eseményről bevillanó emlékképek, pánikrohamok, hisztéria, vagy egyéb szervi megbetegedés vagy sérülés nélkül jelentkezô testi tünetek. Már az ókortól kezdődően rejtély övezte a megjelenő szimptómákat, és jellemzően a legtöbb forrás a harcok során elszenvedett traumáknak tulajdonította ezeket.

Az orvoslás és a pszichológia fejlődésével a tudomány közelebb került a PTSD múködésének megértéséhez, okainak feltárásához. Ma már tudjuk, hogy a PTSD nem csupán a háborúk betegsége, hanem szélsôségesen traumatikus események nyomán alakulhat ki (például nemi erôszak, kínzás), különbözó idegrendszeri és hormonális változások kísérik, il- letve különböző erre hajlamosító tényezők súlyosbíthatják a szindrómát, mint például egyéb pszichiátriai betegségek vagy függőségek.

Jelen tanulmány a PTSD-rôl való tudás fejlődésének rövid összefoglalását célozza meg, bemutatva az ide kapcsolódó történelmi állomásokat az ókortól egészen napjainkig, illetve kiemelve a betegség előfordulásával kapcsolatos adatokat, az ún. DSM (Diagnostic and Statistical Manual of Mental Disorders) általi meghatározása alakulását, a terápiás lehetőségeket.

\section{A PTSD történeti áttekintése}

\section{Ókori emlékek}

A traumákat említő, ókorból fennmaradt írásos emlékek szinte mind a harcok, háborúzás tapasztalatához köthetők. Legkorábban a kora ókori Mezopotámiában találunk írásos bizonyítékot a PTSD tüneteinek megjelenése kapcsán. A Gilgames-eposz első ismert változa- 
tának keletkezése i.e. 2100 környékére tehető. A mű a sumér Gilgames király történetét írja le, aki kénytelen volt végignézni barátja, Enkindu napokig húzódó haláltusáját (1. ábra). Társa elvesztése után Gilgamest állandó rémálmok és visszatérō emlékek kezdték gyötörni, amelyek kínzó tüneteitől hónapokon keresztül képtelen volt szabadulni (Komoróczy, 1974).

\section{1. ábra: Részlet a Gilgames-eposz agyagtáblájáról.} Forrás: Carey, 2020.

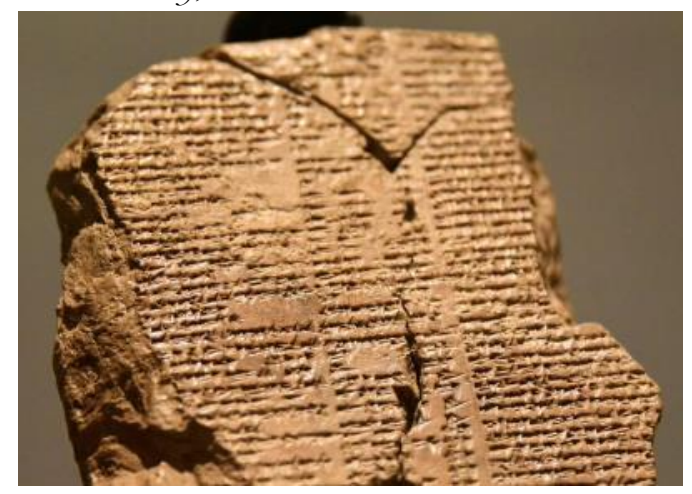

Az Anglia Ruskin Egyetem által végzett friss kutatás szerint már az ókori asszírok is találkoztak a PTSD tüneteivel. A kutatás során olyan agyagtáblákat elemeztek, amelyek keletkezése i.e. 1300 és i.e. 609 közé tehető, és olyan beszámolókat tartalmaznak, amelyek az asszír katonák harc után jelentkező tüneteit írják le, mint például a csatáról bevillanó emlékképek, alvási zavarok vagy depresszív hangulat. A korból fennmaradt ékírásos emlékek arról is beszámolnak, hogy a katonák testét különböző pajzsok, páncélzat vagy fegyverek védték, a harcok miatt elszenvedett lelki traumáktól azonban semmi sem óvta meg őket.

Az ókori Mezopotámiában jellemző volt, hogy a különböző betegségeket az istenek által küldött büntetésnek tulajdonították, amely során az elhunytak szellemei megtámadták a vétkezők testét. Jellemzően a háborúk után a katonáknál jelentkező pszichés tünetek megjelenését is azzal magyarázták, hogy a harcok során meggyilkoltak szelleme bosszút akar állni, emiatt jelentkeztek a kínzó rémálmok vagy egyéb tünetek. A kor orvoslását is ez a szemlélet határozta meg, hiszen a legtöbb gyógyszeres kezeléshez olyan szereket használtak, amelyeknek valamilyen vallási vagy mágikus hatást tulajdonítottak (Abdul-Hamid és Hughes, 2014).

Számos későbbi forrásban is fellelhetők olyan esetek, amelyek a PTSD-hez, traumához köthetők. Az orvostudomány megalapítója, Hippokratész (i.e. 460-370) például beszámolt olyan páciensekről, akik állandó lehangoltsággal, depresszióval, szorongással küzdöttek, beszédük összefüggéstelen volt vagy éppen nem voltak hajlandóak megszólalni. Továbbá katonák vizsgálata kapcsán olyan tipikus tüneteket írt le, mint például az álmatlanság, a rémálmok megjelenése vagy a szorongás.

Hippokratész vizsgálatai alkalmával megfigyelte, hogy a betegségek során a szervezet különböző testnedveket túl-, vagy alul termel, ezzel ezek egyensúlyi állapota megborul. Úgy tartotta, hogy az egészséges testi-lelki múködés a vér, a sárga epe, a fekete epe, és a nyál termelődésének mennyiségével van összefüggésben (Mirnics, 2006; History.com, 2018).

Egy másik ókori görög forrásban Hérodotosz, az első ismert történész, a marathóni csatával foglalkozó írásában megemlíti, hogy 
Epizelus athéni katona, mindenféle testi sérülés elszenvedése nélkül elvesztette látását a csata közben. A leírásból kiderül, hogy Epizelus végignézte, ahogy mellette harcoló társát megölik, majd abban a pillanatban megvakult, látása pedig nem tért többet vissza. Ezt a tünetet ma az ún. konverziós zavar (köznyelven hisztéria) következményeként tarják számon, amely szintén szélsőséges erôvel ható stresszhatás miatt következhet be. A konverziós zavar során általában neurológiai problémának tűnő tünetek jelentkeznek a páciensnél, akinél valójában semmiféle szervi elváltozás nem található. A tünetek azonban valóságosak, a páciens viszont általában nincs tisztában azzal, hogy betegsége mögött valamilyen lelki probléma áll, amely testi problémává fordul át. Epizelus esetében a hisztériás vakság kialakulása egy jól elkülöníthető, traumatikus eseményhez társult (Semmelweis Egyetem, 2020).

Számos ókori forrás említ olyan traumatikus eseményeket, amelyek elszenvedői a PTSDhez klasszikusan köthető szimptómákat éltek át. A történelem ezen szakaszában elsősorban a csatákban, harcokban való részvételhez társították a tünetek megjelenését. Ennek okán a katonai vezetők kénytelenek voltak szem előtt tartani annak lehetőségét, hogy a csaták során a nagy mentális megterhelésnek kitett harcosok viselkedése kiszámíthatatlanná válhat. Hérodotosz feljegyzéseiből kiderül, hogy többek között I. Leónidasz spártai király is tisztában volt ennek lehetőségével, így a siker érdekében a thermophülai csatára (i.e. 480) való felkészülés során elbocsátotta azokat a katonákat, akik képtelenek lettek volna megbirkózni a harcok mentális terhével (Kucmin, Kucmin, Nogalski, Sojuczuk, Jojczuk, 2016).

\section{Források a középkortól a modern korig}

Az ókori forrásokhoz hasonlóan középkor és a kora újkor íróit is megihlették a traumák okozta változatos tünetek, múveikben gyakran központi szerepet kaptak az egyéneket sújtó különböző traumák, illetve ezek utóhatásai. Ugyan e mûvek írói számára nem volt ismeretlen a trauma jelentése, ebben az időszakban még nem beszélhetünk tudományos definícióról.

Jean Froissart francia író 14. századi írásában az egyik főszereplő visszatérō rémálmokkal, az érdeklődés elvesztésével, a lehangoltsággal küzdött. A harcokkal kapcsolatos visszatérő rémálmok pedig Shakespeare ismert királydrámájában, az 1598-ban megjelent IV. Henrik című műben is fellelhetők (Froissart, 1848, idézi Kucmin, Kucmin, Nogalski, Sojuczuk, Jojczuk, 2016).

A PTSD történelme kapcsán fontos megemlíteni Johannes Hofer 1688-ban megjelent disszertációját, amelyben a svájci orvos egy olyan betegséggel foglalkozott, amely zsoldos katonáknál volt gyakori. Hofer az ún. „,nosztalgia" megjelenését annak tulajdonította, hogy a zsoldosok akár hosszú évekig is távol voltak szeretteiktől, az otthonukra hasonlító tájak pedig trigger pontként egy fertőző betegséget, vagyis a honvágyat indították el szervezetükben. A nosztalgia különböző tünetekkel jelentkezett, mint például a letargia, kétségbeesés, alvászavar, vagy szorongás.

A Hofer által definiált, rejtélyes fertőzőbetegségként számon tartott tünetegyüttes nagy hatással volt a kor orvosaira, akik a későbbiekben tovább vizsgálták a betegséget. Többek között Josef Leopold Auenbrugger osztrák orvos is felhívta a figyelmet a nosz- 
talgia jelentőségére az 1761-ben megjelent Inventium Novum című írásában.

Egy hasonló betegség a napóleoni háborúk (1799-1815) idején is felütötte a fejét. Ekkor két katonaorvos, Dominique Jean Larrey ás François Percy „ágyúsokk” („syndrome du vent du boulet") néven foglalták össze azokat az eseteket, amelyek során a személyek nem szenvedtek látható sérülést, azonban mégis fizikai tünetekkel küszködtek (lásd: Birmes, Hatton, Brunet, Schmitt, 2003).

A nosztalgia nem tűnt el az évtizedek során, mitöbb, lassan ,átterjedt” az amerikai kontinensre is, ahol a polgárháború idején (18611865) a katonai táborokban pusztított. Ekkor úgy tartották, hogy a fertőzötteket a nosztalgia vagy azonnal megöli, vagy felerősíti a katonákban már egyébként is lappangó egyéb betegségeket, ezzel minden maradék életerejüket felemésztve. A letargiával, álmatlansággal, étvágytalansággal, heves szívveréssel, légzési nehézségekkel és a távoli otthon hiányával kapcsolatos érzések felerősödésével járó nosztalgia úgy tűnt, hogy leginkább az érzékeny, gyenge akaratú férfiakat támadta. A katonaorvosok rengeteg nosztalgiában szenvedő beteget megvizsgáltak, akik sokszor arról számoltak be, hogy minden áron vissza akarták szerezni az irányítást érzéseik felett, hiszen tudták, hogy ellenkező esetben a fertôzés először reménytelenséghez, ez pedig halálhoz vezet (Clarke, 2007).

A látható sérülések nélkül is fizikai problémákkal küzdő katonákat az 1860-as években Jacob Mendez Da Costa vizsgálta tovább. Megfigyelései során Da Costa arra a következtetésre jutott, hogy a tünetek a szívet körülvevő idegek túlterhelődése miatt keletkeznek, ezzel okozva a tipikusan kardiovaszkulárisnak mutatkozó szimptómákat. Munkája nyomán a betegség a „katona szíve” („soldier's heart”), vagy „Da Costa szindróma” elnevezést kapta.

A 18. században indult ipari forradalom időszakának fellendülése a közlekedés fejlődésére is nagy hatást gyakorolt. A vonatpályák kiépítésével lehetővé vált nagyobb távolságok megtétele kevesebb idő alatt, amely rengeteg embert csábított utazásra, az új közlekedési eszközök használatára. Ezzel egyidőben a vonatbalestek is megsokszorozódtak, amely hatást gyakorolt a PTSD-vel kapcsolatos fogalmaink fejlődésére.

A vonatszerencsétlenségek túlélőin megfigyelt - külső sérülések nélkül bekövetkező tipikus fizikai panaszok és hisztériához hasonlító tünetek (például nehézlégzés, álmatlanság, lehangoltság) rávilágítottak arra a tényre, hogy a betegség nem csupán a katonákat érinti. Az ún. „vasúti gerinc” („railway spine”) kapcsán azt feltételezték, hogy a központi idegrendszerben keletkező lézió, a gerinc zúzódása vagy a sokk okozta distressz miatt alakulhat ki (History, 2018).

\section{A világháborúk hatásai}

A PTSD és annak tünetei különösen nagy kihívást jelentettek az I. világháború (19141918) alatt. Az ütközetek során olyan extrém, kiszámíthatatlan és kezelhetetlen erôsségű ingerek érték a katonákat, amelyek súlyos szövődményekkel jártak. Az akkoriban „tüzérségi sokknak” („shell shock”) nevezett betegség okozott többek között látás- és halláskárosodást, reszketést, álmatlanságot, visszatérő rémálmokat, bevillanó emlékképeket vagy állandó szorongást. A katonai kórházakat elárasztották a súlyos szimptómákkal küszködő 
katonák, akik kezelésre szorultak (2. ábra). Úgy tûnt, hogy a tüneteket a sokk okozza, amit azok az ütközetekben résztvevők tapasztaltak, akiknek a közelében bomba robbant fel. Ugyanakkor más feltételezések szerint a betegség hátterében ideggyengeség állhatott - ezzel magyarázták azt a tényt, hogy a szimptómák olyan katonáknál is kialakultak, akik közelébe sem kerültek felrobbanó bombának.

2. ábra: A „türérségi sokek" tüneteit tapasztaló katona (bal oldalt). Forrás: Schwarz. (2018)

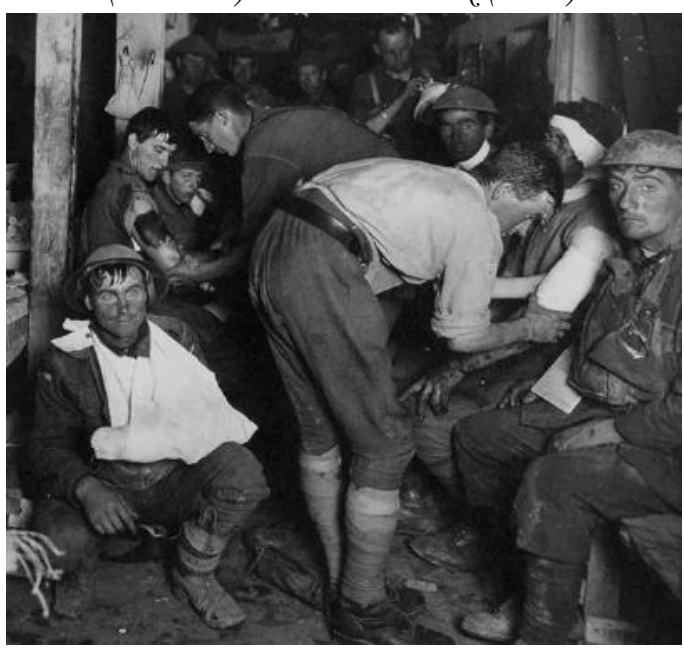

Mivel a tüzérségi sokkra egyelőre nem találták a gyógymódot, így az ellátásban inkább a sokszor igen kegyetlen módszerekkel zajló tüneti kezelésre fókuszáltak: elektrosokk, kondicionálás, a külvilágtól való elzárás gyakori eljárásnak számítottak. A katonákat rendszerint a pár napos kezelés után azonnal visszaküldték a harcmezőre (BBC, 2004).
A II. világháború időszakára (1939-1945) az az általános meglátás vált népszerűvé, miszerint a tüzérségi sokk elterjedésének idején sokszor olyan katonák vettek részt a csatákban, akik egyébként is hajlamosak voltak a szorongásra és neurotikus viselkedésre. Az újabb világháború során ezt a felismerést a katonai vezetők is szem előtt tartották, így a bevonulóknak a szorongásra, idegrendszeri összeomlásra való hajlamot vizsgáló szűréseken kellett részt venniük. Ennek eredményeként rengeteg sorozásra várót utasítottak el, akik így nem vettek részt a harcokban.

A szigorú szabályok ellenére a II. világháború során a PTSD súlyos tünetei újra jelentkeztek a katonák között. A betegséget ekkor „háborús neurózisként” („war neurosis” vagy „combat fatigue”) tartották számon. A gyógyítással kapcsolatos áttörést azonban ez az időszak sem hozta meg. A háborús neurózis kezelése legtöbbször a harcokban való részvétel alóli mentességben, illetve különböző - sikertelen - gyógyszeres kezelésekben merült ki (Pols és Oak, 2007; Reisman, 2016).

A PTSD tünetei a II. világháború után a holokausztot és az azzal együtt járó tragikus megpróbáltatásokat túlélők körében is jelentkeztek, amely a „,koncentrációs tábor szindróma" néven került összefoglalásra.

A kínzó, sokszor élethosszig tartó tünetektôl szenvedők gyógyítása, társadalomba való visszaillesztése hatalmas terhet rótt a háborúkból gyógyuló országokra és az orvostudományra. A korábbi tapasztalatok eredményeként elismerésre került az a tény, hogy a különböző, traumatikus események során bekövetkező nagymértékű stresszhatás súlyos következményekkel jár az ezt átélők pszichés egészségére nézve. 
Az 1952-ben kiadott DSM-I (Diagnostic and Statistical Manual of Mental Disorders, DSM, magyarul Mentális zavarok diagnosztikai és statisztikai kézikönyve, illetve ennek elsô verziója) terminológiájában már szerepel az ún. „súlyos stresszreakció” fogalma, amely megjelenését traumatikus eseményekhez kötötték (például háborús élményekhez).

A PTSD-vel kapcsolatos tudományos kutatások vietnámi háborút (1955-1975) követően kezdtek megsokszorozódni. Számos, a veteránok tüneteinek alakulását éveken át monitorozó és az adatokat összegző kutatás indult el, amelyek hozzájárultak a PTSD-vel kapcsolatos jelenlegi tudásunk alakulásához, a diagnózis egyértelmúbbé válásához.

Ehhez az időszakhoz kötődik a distressz okozásánák és katonai célú felhazsnálásának tudományos kutatása is a lélektani hadviselés tágabb témakörén belül: „A szorongás felkeltése, illetve elnyomása ősidőktől része a (lélektani) hadviselésnek úgyis, mint az ellenség és/vagy a saját oldal neurotizálása, s úgyis, mint az ellenség és/vagy a saját oldal lelki egyensúlyának elõsegítése" (Mező, 2016, 66. o.). A lélektani hadviseléssel kapcsolatban részletesebben lásd: Mező (2014).

\section{A trauma fogalmának alakulása}

Ma már tudjuk, hogy a PTSD kialakulása mögött egy olyan nagy erejű, kezelhetetlen stresszor áll, amely ellen a szervezet képtelen védekezni. A traumatikus esemény bekövetkezése tehát közvetlen okozója a PTSD kialakulásának, az általa elindított pszichés és fiziológiai változások pedig szerteágazó tüneteket okoznak.
A PTSD történeti áttekintése mellett fontos külön említést tenni, az - ehhez szorosan kapcsolódó - trauma fogalmának alakulásáról is, hiszen ez szintén jelentős változásokon ment keresztül az elmúlt évszázadok során.

A trauma szót eredetileg kizárólag az elszenvedett fizikai sérülések leírására használták, míg napjainkban pszichológiai jelentést is hordoz, a személy által elszenvedett lelki megrázkódtatásokra utalva. Mára tipikusan traumának nevezzük az olyan eseményeket, amelyek sokszor erőszakkal, a helyzetből való elmenekülés vagy védekezés lehetőségének hiányával járnak, az elszenvedőt a megsemmisülés veszélye fenyegeti. A nagy erejű fenyegetésre a személy nem tud megfelelően reagálni, szinte megbénul.

A trauma fogalma csupán az 1860-as évektôl kezdett pszichológiai jelentést kapni, amely alakulásához jelentősen hozzájárult többek között Sigmund Freud, Josef Breuer és JeanMartin Charcot munkássága. Freud eredetileg a trauma szót metaforikus értelemben kezdte használni annak szemléltetésére, hogy a testhez hasonlóan a psziché felszínén is keletkezhetnek sebek. A lelki sérülések keletkezésének egyik meghatározó okaként az ún. "háborús neurózist” különítette el. Mára a háborús neurózis fogalma tulajdonképpen a PTSD olyan altípusaként írható le, amely kimondottan a katonákat sújtja a lelkileg is erősen megrázó harci helyzetek átélése kapcsán.

Freud szerint az éles összecsapások, a harctéri helyzetek a személyekre hatalmas erôvel hatnak, teljesen váratlanok és gyökeresen mások, mint ahogyan azt az egyének a harc előtt előzetesen elképzelték. Ez a hirtelen valósággá váló, a kiszámíthatatlan helyzet a katonákban sokszor erős rémületet idéz elő, szinte meg- 
bénítja őket, tehetetlenné válnak, amely élményüket később, jóval a veszély elmúltával is újra átélik, például visszatérő rémálmok formájában. Ezen megfigyelés kapcsán Freud a traumát a következôképp definiálta: “...egy élmény, amely a lelki életet rövid időn belül oly erôs ingernövekedéssel szembesíti, hogy annak elintézése és feldolgozása a normális, megszokott módon nem sikerül..." (Gáti, 2002, 4.). Vagyis a traumatikus esemény bekövetkezésekor a veszélyhelyzet olyan erôvel hat a személyre, hogy képtelen ellene bármilyen módon védekezni (Hatvani, 2015; Garland, 2018).

A freudi trauma definíció tulajdonképpen a mai napig érvényesnek tekinthető, bár a tudomány fejlődésével a traumával kapcsolatos tudásunk tovább árnyalódott, így többek között lehetôvé vált a fiziológiai változások nyomon követése is. A traumatikus események számtalan pszichés betegség origójában állnak szerteágazó tüneteket okozva, amelyeket a történelem során hosszú évszázadokon át rejtély övezett.

\section{A PTSD előfordulása napjainkban}

Napjainkban a PTSD kialakulása és kezelése a traumán átesettek, és a szakemberek számára is igen nagy kihívást jelent, hiszen a betegség súlyos szövődményekkel, a magatartás átformálódásával, a hétköznapokat megkeserítő, hosszan elnyúló, intenzív tünetekkel jár. Különösen nagy fenyegetésnek vannak kitéve a különböző - korábbi felmérések alapján karakterizált - rizikócsoportok, mint például a katonák, rendőrök, egészségügyben dolgozók, vagy tűzoltók (lásd például: Sáfrány, 2021). Számukra már mindennapi munkájuk is a tra- umatizálódás esélyével jár, ennek esetleges bekövetkezése pedig további súlyos következményeket hozhat magával.

A PTSD kialakulásában általában olyan akutan fellépő, kezelhetetlen mértékű stresszorok játszanak szerepet, amelyek ellen a szervezet képtelen védekezni. A stresszorok ezen típusa olyan erővel hat, hogy már egyszeri jelentkezésével tartós vagy végleges magatartásbeli és élettani változásokat okoz. Amennyiben a fenyegetés hosszú ideig fennáll (például: katonai szolgálat a harctéren), úgy ez az állapot könnyen krónikussá válhat, ezzel a PTSD megjelenése mellett növelve a depresszió vagy szorongás kialakulásának esélyét is.

Egyes felmérések adatai alapján a populáció kb. 60\%-a válik élete során valamilyen traumatikus esemény elszenvedőjévé. Ezen személyek kb. 10-20\%-ánál alakul ki PTSD (Kessler és mtsai., 2008; Perczel-Forintos, 2018), más kutatások ezt a számot akár 30\%ra is becsülik (Perczel-Forintos és Lisincki, 2020).

Amellett, hogy a PTSD a populáció jelentős részét érinti, a betegség igen változatos, az egyén életét súlyosan megnehezítő tünetekkel és hatással jár, amelyek irányzott terápiás kezelések nélkül még súlyosabb következményeket hozhatnak magukkal. Ezen tényezők indokolják az egyének megfelelő kezelésben való részesítését, a tünetek orvoslását célzó terápiás folyamat elindítását, a betegség szűrését.

Nem csupán egy traumatikus esemény bekövetkezése, vagy a későbbiekben tárgyalásra kerülő diagnosztikai kritériumok kimerítése, hanem a különböző hajlamosító tényezők is befolyásolják a PTSD kialakulását. Ilyen pél- 
dául a genetikai hajlam, vagyis az olyan befolyásoló gének vagy neurotranszmitterek (például: szerotonin transzporter, katekolamin ometil transzferász, neurotróf faktor) jelenléte és mértéke a szervezetben, amelyek a különböző mentális betegségek - nem csupán a PTSD - kialakulásának esélyét növelik. Ezen gének fokozzák a félelmi memória kifejlődését, illetve a felépülés esélyét is csökkentik.

Az egyén korábbi tapasztalatai, élményei is nagy hatással vannak a betegség megjelenésére, hiszen az ezek nyomán kialakuló pszichiátriai zavarok, illetve nem adaptív megküzdési stratégiák szintén növelhetik a PTSD bekövetkezésének valószínúségét.

Hasonlóan az egyéb pszichiátriai betegségekhez, a PTSD kapcsán sem lehet figyelmen kívül hagyni a környezet szerepét. Az egyént a megküzdésben nem támogató, a fejlődést ellehetetlenítő, destruktív környezet könnyen közvetett/közvetlen okozója lehet a betegség kialakulásának.

A szakirodalom továbbá a szerhasználatot, illetve a korábban elszenvedett agyi sérüléseket is egyértelmű rizikótényezőként említi (Balázsfi, 2017).

\section{A DSM általi meghatározás alakulása}

A történelem során rengeteg kísérlet történt arra vonatkozóan, hogy a mentális zavarok különböző rendszerek mentén osztályozásra kerüljenek. A diagnosztika és gyógyítás szempontjából alapvető jelentőséggel bír, hogy a tudomány jelenlegi állása szerint összesítve, illetve kategóriákba sorolhatók legyenek ezen betegségek. Napjainkban az Amerikai Pszichiátriai Társaság (APA) szerkesztésében álló
DSM a legelterjedtebb kézikönyv a különböző mentális zavarok diagnosztikája kapcsán (American Psychiatric Association, APA, 2020).

Elsőként az 1952-ben kiadott DSM-I-ben szerepel a PTSD fogalmához szorosan kapcsolható meghatározás. Ekkor olyan súlyos stressz reakcióként írták le, amely traumatikus eseményekből származik, de tünetei 6 hónapon belül elmúlnak. A PTSD-t hivatalosan az 1980-ban megjelent DSM-III-ban ismerték el. Ekkor úgy tartották, hogy kialakulása azért következhet be, mert a személy egy olyan traumás eseményen esik át, amely a szokványos emberi tapasztalatok körén kívül esik, vagyis ehhez hasonló esemény megtapasztalása mindenkinél szorongást váltana ki. Ide sorolták többek között a természeti katasztrófák, a harctéri stressz, a holokauszt, vagy a szexuális bántalmazások túlélőit (Gáti, 2002).

A DSM következő kiadványaiban (DSM-IV és DSM-IV-TR) a PTSD kritériumai az akkor folyamatban lévő kutatások eredményeként kisebb-nagyobb változtatáson estek át, azonban jelentős módosítás csak a legfrissebb, 2013-ban megjelent DSM-V-ben történt.

A korábbi kiadások a PTSD-t szorongásos zavarok közé sorolták, azonban a DSM-V-ben egy új kategória is megjelent a traumával és stresszel összefüggő betegségek csoportosítására. A változtatásra azért volt szükség, mert míg a szorongásos zavarok kialakulásának hátterében sokszor diffúz, nem egyértelmű okok állnak, addig a PTSD-rôl tudjuk, hogy traumatikus események átélésének hatására jelentkezik. Ezen felül a PTSD sokszor hangulati zavarokkal is együtt jár (például: depresszió), azonban ez a szorongásos zavarokra nem feltétlenül jellemző. Az eltérő okok, intenzitás és 
magatartásbeli változások ellenére a PTSD sok szempontból szorosan összefügg a szorongásos zavarokkal. Ilyen például az a tényező, hogy a szorongásos zavarokra jellemző tünetek a PTSD-ben is megjelennek, azonban itt legtöbbször nem külön-külön, hanem egyszerre jelentkeznek (például anhedónia, diszfória, externalizáló harag).

A DSM-V különböző kritériumokat sorol fel a PTSD kapcsán, amelyek közül legalább egynek teljesülnie kell a diagnózis felállításához. Ilyen kritérium a traumás stresszor megléte, vagyis valós vagy fenyegető komoly sérülés, halál, szexuális erőszak lehetôségének megtapasztalása. A PTSD kialakulásához a személynek nem kell közvetlenül a történés elszenvedőjének lennie, a betegség kialakulhat akkor is, ha az illetô szemtanúként volt jelen az esemény bekövetkezésekor.

Az időbeli lefolyás kapcsán további kritérium, hogy a tünetek több, mint egy hónapig kell, hogy fennálljanak. Ezek nem feltétlenül jelentkeznek közvetlenül az esemény után, van, hogy hónapok, vagy akár évek is eltelnek kialakulásukig.

A DSM-V többek között jellemző tünetként említi az élmények újra átélésével kapcsolatos szimptómákat. Ide sorolhatók a különbözó, spontán felszínre törő, intruzív tünetek (például betörő emlékképek), a visszatérő álmok vagy a traumás esemény során átélt fiziológiai és pszichés jellemzők újra átélése ún. „flashback-ek" formájában. Az elkerülő magatartás kialakulása is általában jellemző, vagyis a személy a traumás eseménnyel összefüggő ingereket tartósan kerüli, állandó készenléti állapotban van, folyamatosan monitorozza környezetét, amely okán koncentrációs képessége beszűkül. Negatív gondolatok, hangulati zava- rok, disszociatív szimptómák (például deperszonalizáció, derealizáció) is jelentkezhetnek tünetként (APA, 2013; Balázsfi, 2017).

\section{Terápia}

Mint a legtöbb pszichés betegségre, úgy a PTSD-re is igaz, hogy a pszichoterápia és a gyógyszeres kezelés együttes alkalmazása adja a legnagyobb esélyt a gyógyulásra.

Jelenleg a PTSD gyógyításában a legeredményesebb terápiás módszerként a kognitív viselkedésterápiát (CBT: cognitive behavioral therapy) tartják számon, amely a szorongásos és depresszív kórképek kezelésében bizonyítottan nagy hatékonysággal bír (De Rubeis, Hollon, Amsterdam, 2005; Mayo-Wilson, Dias, Mavranezouli, 2014). A terápia az irreálisan negatív gondolatok, attitűdök és az ezek által kialakított torzult viselkedés módosítását célozza meg. Az ülések során a páciensnek lehetősége nyílik annak megtapasztalására és megértésére, hogy az átélt trauma utóhatásaként keletkező negatív gondolatai, a testérzeteire való túlzott fókuszálása eltorzítják a valóságészlelését, ezzel irreális mértékű szorongást okozva. A terápia eredményeként az egyénnek pontosabb képe alakulhat ki arról, hogyan értelmezi túlzottan fenyegetőnek - az egyébként veszélytelen - ôt körülvevő hétköznapi helyzeteket. A páciens tudatosabbá válásával emocionális tünetei enyhülnek, szorongása oldódik, viselkedése adaptívabbá válik. Lehetőség nyilik a feldolgozásra, megbékélésre, az önvédelem elsajátítására, és a hosszútávú gyógyulásra. Ezen tényezők lehetővé teszik, hogy a páciens visszailleszkedjen a hétköznapi élet rendszerébe, új jövőképet alakítson ki, vagy akár poszttraumás növekedésen 
menjen keresztül így találva új célokat és motivációkat (Perczel-Forintos és Mórotz, 2019; Vizin és Farkas, 2020).

A kognitív viselkedésterápia széles eszköztárral rendelkezik a traumákkal, szorongásos zavarokkal kapcsolatos megbetegedések kezelésére. A PTSD szempontjából az egyik leghatékonyabb módszer az ún. „hosszan tartó expozíciós terápia” („prolonged exposure therapy”), melynek során a pácienst újra szembesítik az átélt traumára emlékeztető helyzettel, azonban ezúttal biztonságos körülmények között (pl. virtuális valóság használatával) (Fodor és Bitter, 2015; Maples-Keller és mtsai., 2017, idézi Balázsfi 2017).

Ami a PTSD farmakológiai kezelését illeti, a szerotonin szint szabályozásán keresztül ható antidepresszánsok (például sertralint és paroxetint tartalmazó készítmények) használata ajánlott. Tüneti kezelés kapcsán elterjedtek a szorongásoldók, illetve a neurotranszmitterekre ható gyógyszerek az álmatlanság, vagy rémálmok ellen (Balázsfi, 2017; National Institute for Health and Care Excellence, NICE, 2018).

\section{Összefoglaló}

A traumatikus események bekövetkezése, hatásaik eszkalálódásának lehetôsége, az ezekből következő pszichológiai és fizikai tünetek feloldásának igénye életünk velejárója, amelynek írásos bizonyítékait már az ókorban is megtalálhatók, azonban ennél még sokkal régebbre, az emberi lét kezdetéhez nyúlnak vissza. A történelmi összefoglalók bizonyítják, hogy a PTSD - még, ha elnevezése és karakterisztikája folyamatosan változott is az évszázadok során - mindig is a pszichológia és az orvostudomány érdeklődésnek középpontjában állt. Tanulmányunk elkészítésének célja e folyamat bemutatása volt az évszázadokat felölelő írásos emlékekben megjelenő kutatási eredmények, a betegség megismerésére, diagnosztizálására, kezelésére és szakmai definiálására történő törekvések összefoglalásán keresztül. A PTSD-hez kapcsolható fogalmak fejlődése, a DSM-ben található definíció evolúciója ugyancsak jól szemlélteti a tudomány fokozatos érdeklődésének kibontakozását a téma iránt.

A betegség megelőzése, kezelése napjainkig állandó kihívást jelent a szakemberek számára. A betegség okaival, alakulásával kapcsolatos tapasztalatok mára komplex, valós segítséget nyújtó, eredményes kezelési módok létrejöttét indikálták. A pszichológia szempontjából fontos szem előtt tartanunk, hogy a PTSD következményei a traumán átesett személyek életét súlyosan megnehezítik, a megoldatlan probléma pedig könnyen további szövődményeket hozhat. A traumán átesettek, illetve a PTSD kialakulására különösen veszélyeztetett rizikócsoportok esetében a megfelelő segítség biztosítása, a feldolgozás megkönnyítése elengedhetetlen.

A PTSD-vel kapcsolatos további kutatások fontosak ahhoz, hogy tudásunk tovább gyarapodhasson a betegség kapcsán, akár a rizikófaktorokat, rezíliencia vagy a mentális állóképesség szerepét illetően.

\section{Irodalom}

Abdul-Hamid, W. K., \& Hughes, J. H. (2014). Nothing New under the Sun: Post-Traumatic Stress Disorders in the Ancient World. Early Science and 
Medicine(19), old.: 1-9. DOI:

10.1163/15733823-00196p02

American Psychiatric Association (APA). (2013). Diagnostic and Statistical Manual of Mental Disorders: DSM-5. Washington: American Psychiatric Press Inc.

American Psychiatric Association (APA). (2020). DSM History. Letöltés: 2021.03.01. Web:https://www.psychiatry.org/psychia trists/practice/dsm/history-of-the-dsm

Balázsfi D. G. (2017). Poszttraumás stressz. szindróma kialakulásának hátterében álló glutamáterg folyamatok tanulmányozása állatmodellben. Budapest: Semmelweis Egyetem.

BBC. (2004). Shell Shock. Letöltés: 2021. 03.28 .

Web:http://www.bbc.co.uk/insideout/ex tra/series-1/shell_shocked.shtml

Birmes, P., Hatton, L., Brunet, A., \& Schmitt, L. (2003). Early historical literature for post-traumatic symptomatology. Stress and Health, 19(1), 17-26.

Carey, J. (2020). The Epic of Gilgamesh.

Letöltés: 2021.04.03. Web:

http://blog.yalebooks.com/2020/04/30/ the-epic-of-gilgamesh/

Clarke, F. (2007). So Lonesome I Could Die:

Nostalgia and Debates over Emotional Control in the Civil War North. Journal of History, 41(2), 253-282. DOI: $\underline{10.1080 / 00332747.2020 .1845055}$

De Rubeis, R. J., Hollon, S. D., \& Amsterdam, J. D. (2005). Cognitive therapy vs. medications in the treatment of moderate to severe depression. Archives of General Psychiatry(62), 409-416. DOI: $\underline{10.1001 / \text { archpsyc.62.4.409 }}$
Fodor K. E., \& Bitter I. (2015). Pszichológiai intervenciók traumatikus események után a poszttraumás stressz zavar megelőzésére. Orvosi Hetilap, 156(33), 1321-1334. DOI: 10.1556/650.2015.30231

Garland, C. (2018). Understandng Trauma: A Psychoanalytical Approach. Abingdon:

Routledge.

Gáti Á. (2002). Pszichotraumák patogenetikai és terápiás vonatkozásai. Pécs: Pécsi Tudományegyetem.

Hatvani A. (2015). A trauma lélektana. In Eszterházy Károly Főiskola, Trauma és válság a századfordulón (old.: 77-86). Eger: Líceum Kiadó.

History.com. (2018). PTSD and Shell Shock. Letöltés: 2021.03.08. Web: https://www.history.com/author/history

Kessler, R. C., Berglund, P., Demler, O., Jin, R., Merikangas, K. R., \& Walters, E. E. (2008). Lifetime prevalence and age-ofonset distributions of DSM-IV disorders in the National Comorbidity Survey Replication. Archives of General Psychiatry, 593-603. DOI 10.1001/archpsyc.62.6.593

Komoróczy G. (1974). Gilgames agyagtáblák üzenete. Budapest: Európa Könyvkiadó.

Kucmin, T., Kucmin, A., Nogalski, A., Sojuczuk, S., \& Jojczuk, M. (2016). History of trauma and posttraumatic disorders in literature. Psychiatria Polska, 50(1), 269-281. DOI: $10.12740 / \mathrm{PP} / 43039$

Mayo-Wilson, E., Dias, S., \& Mavranezouli, I. (2014). Psychological and pharmacological interventions for social anxiety disorder in adults: a systematic review and network meta-analysis. Lancet 
Psychiatry(1), 368-376. DOI:

10.1016/S2215-0366(14)70329-3

Mezõ Ferenc (2014): PSYOPS - avagy:

kalando-zás a hadak útján, a pszichológia

ösvényein, a történelem útvesztỗiben. Debrecen,

Kocka Kör

Mező Ferenc (2016): Prognosztizálható

változások az emberi tényezõk mentén

katonai aspektusból. Hadtudomány,

XXVI.évf. különszám (2016. december).

59-68.o. DOI:

10.17047/HADTUD.2016.26.K.59

Mirnics Zs. (2006). A személyiség épitókövei.

Budapest: Bölcsész Konzorcium.

National Institute for Health and Care

Excellence (NICE). (2018). Post-traumatic

stress disorder: Evidence reviews for psychological,

psychosocial and other non-pharmacological

interventions for the prevention of PTSD in

adults. London: NICE.

North, C. S., Suris, A. M., Davis, M., \&

Smith, R. P. (2008). Toward validation of the diagnosis of posttraumatic stress

disorder. American Journal of Psychiatry, 34-

41. DOI:

10.1176/appi.ajp.2008.08050644

Perczel-Forintos D. (2018). "Miért éppen velem

történik?". Kognitiv terápiás intervenciók PTSD

esetén. Letöltés: 2021.03.28. Web:

https:// semmelweis.hu/klinikai-

pszichologia/files/2018/11/PTSD_CBT

_szakkpzs2018b.pdf

Perczel-Forintos D., \& Lisincki A. (2020). A

PTSD kezelése a NICE irányelvek alapján.

Letöltés: 2021.03.28. Web:

https:// semmelweis.hu/klinikai-

pszichologia/files/2020/04/PTSD-

kezelésének-NICE-irányelvei.pdf
Perczel-Forintos D., \& Mórotz K. (2019). A kognitív terápia standard módszerei és hatótényezői. In D. Perczel-Forintos, Kognitív viselkedésterápia. Budapest:

Medicina Kiadó.

Pols, H., \& Oak, S. (2007). War \& Military Mental Health. American Journal of Public Health, 97(12), 2132-2142. DOI:

10.2105/AJPH.2006.090910

Reisman, M. (2016). PTSD Treatment for Veterans: What's Working, What's New, and What's Next. Physical Therapy, 41(10), 632-634. PMCID: PMC5047000

Sáfrány Judit (2021): Poszttraumás stressz zavar és krízisintervenció a hivatásos tűzoltó populációban. Lélektan és hadviselés - interdiszciplináris folyóirat, III. évf. 2021/1. szám. 37-50. DOI:

10.35404/LH.2021.1.37

Schwarz, N. (2018). What World War I taught us about PTSD. Letöltés: 2021.04.10. Web: https://theconversation.com/whatworld-war-i-taught-us-about-ptsd-105613

Semmelweis Egyetem. (2020). Konverziós zavar. Letöltés: 2021.03.12. Web: https://semmelweis.hu/klinikaipszichologia/betegellatas-es-szakmaiprofilok/szakambulanciank-profiljabanem-tartozo-zavarok/konverzios-zavar/

Vizin G. és Farkas K. (2020). A kognitív viselkedésterápia lehetőségei az onkológiai ellátásban. Magyar Onkológia, 64(1) 62-69. PMID: 32181764 